\title{
Assessment of Potential Duo Out of Syzigium aromaticum L., Zingiber officinale and Ocimum basilicum L. Leaves Extract for Extermination of Clinical Pathogens
}

\section{Pratik M. Bezalwar ${ }^{1 *}$ and Abha S. Manapure ${ }^{2}$}

${ }^{1}$ Arts, Commerce and Science College, Koradi, Dist. Nagpur, India

${ }^{2}$ Department of Microbiology, Samarth Mahavidyalaya, Lakhani, India

\begin{abstract}
In last three decades numbers of new antibiotics have produced, but clinical efficacy of these existing antibiotics is being threatened by the emergence of multi drug resistant pathogens. This has forced scientist to search for new antimicrobial substances from various sources like the medicinal plants. Scope of this study is to evaluate the potential duo of Syzigium aromaticum L., Zingiber Officinale and Ocimum basilicum L against clinical pathogens; $E$. coli, S. aureus, B. cereus and $P$. vulgaris. Well diffusion method was adopted to study antimicrobial properties. The maximum zone of inhibition is produced by Syzigium aromaticum than other extracts $S$. aureus $(17 \mathrm{~mm})$ followed by $B$. cereus and $P$. vulgaris. Duo of Syzigium aromaticum and Zingiber officinale shown to have maximum antimicrobial property against $E$. coli, S. aureus, B. cereus and $P$. vulgaris which is expressed to be a best duo of extract and it is more potent $(25 \mathrm{~mm})$ for $B$. cereus. Duo of Zingiber Officinale and Ocimum basilicum and Ocimum basilicum and Syzigium aromaticum was least effective but in conclusion combined action of these extract is more enhanced than the individual extract. Our study indicates that phytoconstituents in combination can act better than individual. Therefore, they can be used for preserving various foodstuffs against microbial spoilage and it can be incorporated into medications for topical antifungal or antibacterial therapy.
\end{abstract}

Keywords: Syzigium aromaticum L., Zingiber officinale and Ocimum basilicum

\section{Introduction}

Infectious diseases caused by pathogens; bacteria, fungi, viruses and parasites are still a major threat to public health in spite of tremendous progress in human medicines [1]. Plant kingdom represents an extraordinary reservoir of novel molecules [2]. Nature has itself provided an important source of remedies to cure various ailments of mankind. Plants have been a rich source of bioactive compounds to treat many diseases. Medicinal plants produce a variety of compounds with known therapeutic properties which is been traditionally used [3]. In recent years, all the medicines used were from natural source, especially from plants [4]. Plants contain hundreds or thousands of metabolites. For bactericidal, virucidal, fungicidal, antiparasitical, insecticidal, medicinal, cosmetic, agricultural, food industries and cosmetic applications essential oils have widely been used. In recent times plants also have been exploited for pharmaceutical and sanitary purpose. Extraction by hydrodistillation from aromatic plants, they contain a variety of volatile molecules such as terpenes and terpenoids, phenol-derived aromatic components, and aliphatic components [5]. Medicinal and aromatic plants are gift of nature, which is being used against various infectious diseases and other curative purpose. Very small of total percentage of plants species have been exploited and investigated for their curative potential and very few fraction is screened for phytochemistry [6]. Nutraceuticals are plants which contribute their phytonutrients and other compounds for maintaining a good and healthy life. There is strong correlation between diet and the incidence of diseases [7]. Study over toxicity profile of most medicinal plants has not been evaluated totally but a strong belief of ayurveda accepted that plant derived medicines far safer than their synthetic medicine [8].

Public health is tremendously threatened by infectious diseases caused by bacteria, fungi, viruses and parasites although antibiotics have made a strong influence for control of disease caused by pathogens and emergence of widespread drug (antibiotic) resistance for such pathogens turned the path of pharmacological companies to search for potent drug target [9].

Plants have been widely used for the treatment of various ailments in animals. In the study of McGaw and Eloff reported that near about 200 plant species used as ethnoveterinary medicine in South Africa. For the benefits of humans and animals again more species need to be evaluated in depth [10].

The plant species used in this study were chosen based on documented traditional use. Because some commercial antibiotic are not responding to bacterial pathogens and emergence of multi drug resistance, we decided to investigate the possible solution to overtake such pathogens by investigating potential duo of plant extract. Ethyl acetate was selected as the only solvent based on its ability to extract compounds with a wide range of polarities, its low toxicity in antimicrobial bioassays and because it is easily removed from the extract at low temperature. The present study aims to review traditional ethno medicinal knowledge of the local people in local spices and focusing specifically on the medicinal uses of plants. These types of studies are

*Corresponding author: Pratik M. Bezalwar, C/O Mithun V. Ragenwar, Plot 66, Gondwana nagar 2, Beltarodi Road, Nagpur-4400015, India, E-mail: pratikmbezalwar@gmail.com

Received February 11, 2015; Accepted March 26, 2015; Published March 28 2015

Citation: Bezalwar PM, Manapure AS (2015) Assessment of Potential Duo Out of Syzigium aromaticum L., Zingiber officinale and Ocimum basilicum L. Leaves Extract for Extermination of Clinical Pathogens. J Plant Pathol Microb 6: 265. doi:10.4172/2157-7471.1000265

Copyright: ( 2015 Bezalwar PM, et al. This is an open-access article distributed under the terms of the Creative Commons Attribution License, which permits unrestricted use, distribution, and reproduction in any medium, provided the original author and source are credited. 
urgent considering the loss of traditional knowledge accompanying alteration of the physical and biological environment.

\section{Material and Methods}

\section{Collection of clinical samples}

Clinical samples were collected from regional pathology laboratories Bhandara district. Each sample was then preceded for battery of biochemical, cultural and morphological test for isolation and confirmation of E. coli, S. aureus, B. cereus and P. vulgaris. The isolated pure cultures were maintained on nutrient agar till its use at $4^{\circ} \mathrm{C}$ in refrigerator.

\section{Collection of plant material}

Syzigium aromaticum L., Zingiber officinale and Ocimum basilicum L. was collected from vegetable market of Bhandara district.

\section{Extract preparation from herb}

$5.0 \mathrm{~g}$ of powder of dried clove was mixed in $50 \mathrm{ml}$ of ethyl acetate. The mixture was kept in dark condition at room temperature for 2 days. After 2 days slurry was filtered through Whatmann filter paper no. 1 and filtrate was concentrated by evaporation in hot air oven and volume is reduced to $10 \mathrm{ml}$.

For single extract activity direct $100 \mu \mathrm{l}$ extract is used out of reduced $10 \mathrm{ml}$ extract and for duo action $50 \mu \mathrm{l}$ extract of each member in combination is used.

\section{In vitro susceptibility testing of extract}

Hi-sensitivity test broth was prepared and sterilized at $15 \mathrm{lbs}$ for 15 min. and inoculated with the previously screened antibiotic resistant bacteria aseptically. Separately, sterile Hi-sensitivity test agar plates were prepared and allowed it to solidify at room temperature. A 0.5 $\mathrm{ml}$ of 6-8 hours old test organism was inoculated in solidified sterile Hi-sensitivity test agar plates and spread with sterile spreader. Wells were cut in previously solidified sterile $\mathrm{Hi}$-sensitivity test agar plates with the help of $10 \mathrm{~mm}$ cork borer. A $100 \mu \mathrm{l}$ of previously prepared Syzigium aromaticum L., Zingiber officinale and Ocimum basilicum L. extract was transferred by micropipette per well and for duo action 50 $\mu \mathrm{l}$ extract of each member in combination was used. Separate plate was used for each concentration. Plates were then incubated at $35 \pm 0.5^{\circ}$. Zone of inhibition was measured after $24 \mathrm{hrs}$ of incubation.

\section{Result and Discussion}

Total four test organisms isolated from clinical samples are used in the study. Clinical isolates of E. coli, S. aureus, B. cereus and P. vulgaris were used in the study. For the first part of experiment were extract (alone) was tested; Extracts of Syzigium aromaticum L., Zingiber officinale and Ocimum basilicum L. against clinical isolates of E. coli, $S$. aureus, B. cereus and $P$. vulgaris, the maximum zone of inhibition is produced by Syzigium aromaticum than other extracts, and Syzigium aromaticum showed maximum zone of inhibition for $S$. aureus (17 $\mathrm{mm}$ ) followed by B. cereus and P. vulgaris with zone of inhibition of 15 $\mathrm{mm}$ and showed least zone of inhibition of $11 \mathrm{~mm}$ whereas Ocimum basilicum extract have almost same inhibition property against all test organisms and least antimicrobial property exhibited by Zingiber officinale (Table 1).

For the second part of experiment were extract in combination (duo) was tested; three duo of extract is prepared and differential results were obtained. Duo of Syzigium aromaticum and Zingiber officinale shown to have maximum antimicrobial property against E. coli, $S$. aureus, $B$. cereus and $P$. vulgaris which is expressed to be a best duo of extract and it is more potent (25 mm) for B. cereus. Duo of Zingiber officinale and Ocimum basilicum and Ocimum basilicum and Syzigium aromaticum was least effective but in conclusion combined action of these extract is more enhanced than the individual extract (Table 2).

Plants contain several phytochemicals inhibit several pathogens. Selected also contain such compounds that are able to inhibit clinical pathogens among all Syzigium aromaticum extract was better in respect of antimicrobial property. The results of Burst and Reinders [11] that clove oil was found effective against strains of E. coli O157:H7 [11]. Strains of $S$. aureus are inhibited by clove extract which supports the present study [12]. Similar study of Lopez et al. [13] over clove oil was found active against Staphylococcus aureus, Bacillus cereus, Enterococcus faecalis and Listeria monocytogenes and E. coli, Yersinia enterocolitica, Salmonella choleraesuis and P. aeruginosa [13]. Lokesh et al. [14], Verma et al. [15] demonstrated that clove extract to have antibacterial properties along different elicitors including sugars and metal ions $[14,15]$. Phyto-constituents analysis of clove found to have rhamnocitrin, biflorin, ellagic acid, gallic acid, kaempferol, myricetin, and oleanoic acid confers antibacterial activities against Streptococcus mutans, Actinomyces viscosus, Porphyromonas, Helicobacter pylori and Prevotella intermedia [16-18].

Prasad et al. [19] proved essential oil of O. basilicum have the better antimicrobial activity of against Gram-negative than Gram-positive bacteria [19]. Sinha and Gulati, Prasad et al., [19]; Opalchenovaa and Obreshkova [20] demonstrated the effectiveness of the $O$. basilicum against S. aureus, Salmonella paratyphi, Proteus vulgaris, Salmonella typhi, Shigella boydi, and E. coli the results are in harmony with present studies $[19,20]$.

Singh et al. [21] discussed the differences in the effectiveness of antimicrobial potency, this difference in concentration could be due to the nature of solvent and method of extraction [21]. Because of differences in cell wall composition, the resistance of the Gram-negative bacteria could be due to the complexity of the cell wall and the external membrane of Gram-negative bacteria renders highly hydrophilic surfaces whereas the negative charge of the surface of the Grampositive wall reduces their resistance to antibacterial compounds [22] A component monoterpen have antibacterial property activity because of the disruption of bacteria or fungal membrane Integrity [23].

\begin{tabular}{|c|c|c|c|c|}
\hline \multirow{2}{*}{ Sr. No. } & \multirow{2}{*}{$\begin{array}{c}\text { Test } \\
\text { organisms }\end{array}$} & $\begin{array}{c}\mid 3 \\
\text { Syzigium } \\
\text { aromaticum }\end{array}$ & $\begin{array}{c}\text { Zingiber } \\
\text { officinale }\end{array}$ & Ocimum basilicum \\
\hline 1 & E. coli & $11 \mathrm{~mm}$ & $10 \mathrm{~mm}$ & $17 \mathrm{~mm}$ \\
\hline 2 & S. aureus & $17 \mathrm{~mm}$ & $12 \mathrm{~mm}$ & $18 \mathrm{~mm}$ \\
\hline 3 & B. cereus & $15 \mathrm{~mm}$ & $11 \mathrm{~mm}$ & $\mathrm{Nil}$ \\
\hline 4 & P. vulgaris & $15 \mathrm{~mm}$ & $14 \mathrm{~mm}$ & $17 \mathrm{~mm}$ \\
\hline
\end{tabular}

Table 1: Zone of inhibition of extracts (alone) against test organism.

\begin{tabular}{|c|c|c|c|c|}
\hline \multirow{2}{*}{ Sr. No. } & \multirow{2}{*}{$\begin{array}{c}\text { Test } \\
\text { organisms }\end{array}$} & $\begin{array}{c}\text { Syzigium } \\
\text { aromaticum + } \\
\text { Zingiber officinale }\end{array}$ & $\begin{array}{c}\text { Zingiber officinale } \\
\text { + Ocimum } \\
\text { basilicum }\end{array}$ & $\begin{array}{c}\text { Ocimum } \\
\text { basilicum } \\
\text { + Syzigium } \\
\text { aromaticum }\end{array}$ \\
\hline 1 & E. coli & $19 \mathrm{~mm}$ & $13 \mathrm{~mm}$ & $17 \mathrm{~mm}$ \\
\hline 2 & S. aureus & $21 \mathrm{~mm}$ & $18 \mathrm{~mm}$ & $15 \mathrm{~mm}$ \\
\hline 3 & B. cereus & $25 \mathrm{~mm}$ & $18 \mathrm{~mm}$ & $21 \mathrm{~mm}$ \\
\hline 4 & P. vulgaris & $20 \mathrm{~mm}$ & $16 \mathrm{~mm}$ & $14 \mathrm{~mm}$ \\
\hline
\end{tabular}

Table 2: Zone of inhibition of extracts in different duo against test organism. 
Ginger is effective against Escherichia coli, Pseudomonas aeruginosa, Staphylococcus aureus, Vibrio cholerae, Klebsiella spp. and Salmonella spp. [24]. Hot extract of ginger extract (crude) loss its antimicrobial activity against Klebsiella pneumoniae, Escherichia coli and Staphylococcus aureus. Onyeagba et al. [25] demonstrated synergistic effect of ethanol extract of ginger and garlic against Bacillus spp. and Staphylococcus aureus which supports the present research $[25,26]$.

The result revealed that, Syzigium aromaticum L., Zingiber officinale and Ocimum basilicum L have antimicrobial activity. On the other hand, combination these extract is more potent than alone for extermination of clinical pathogens.

\section{Conclusion}

Our experimental data suggests that Syzigium aromaticum L., Zingiber officinale and Ocimum basilicum L have antimicrobial activity and combination these extract is more potent than alone for extermination of clinical pathogens. This inferred that phytoconstituents in combination can act better than individual. From the obtained results of our present study we can indicate that combined extracts have exhibited wide spectrum of antimicrobial properties. Therefore, they can be used for formulation of pharmaceutical products and preservation of various foodstuffs against microbial spoilage.

\section{References}

1. Arya V, Yadav S, Kumar S, Yadav JP (2010) Antimicrobial activity of Cassia occidentalis $L$ (leaf) against various human pathogenic microbes. Life Sci Med Res 9: 1-11.

2. Hema R, Kumaravel S, Elanchezhiyan N (2009) Antimicrobial activity of some of the South-Indian spices and herbals against food pathogens. Global J Pharmacol 3: 38-40.

3. Chopra RN, Nayer SL, Chopra IC (1992) Glossary of Indian Medicinal Plants. (3rdedn) New Delhi: Council of Scientific and Industrial Research. 3-329.

4. Singh CR (2011) Antimicrobial effect of callus and natural plant extracts of Premna serratifolia L. Int J Pharm Biomed Res 2: 17-20.

5. Bakkali F, Averbeck S, Averbeck D, Idaomar M (2008) Biological effects of essential oils--a review. Food Chem Toxicol 46: 446-475.

6. Lalitha V, Raveesha KA, Kiran B (2010) Antimicrobial activity of Solanum torvum Swart. against important seed borne pathogens of paddy. Iranica J Energy Environ 1: 160-164.

7. Kandaswami C, Lee LT, Lee PP, Hwang JJ, Ke FC, et al. (2005) The antitumor activities of flavonoids. In Vivo 19: 895-909.

8. Vongtau HO, Abbah J, Chindo BA, Mosugu O, Salawu AO, et al. (2005) Central inhibitory effects of the methanol extract of Neorautanenia mitis root in rats and mice. J Pharm Biol. 43: 113-120.

9. Okeke IN, Laxminarayan R, Bhutta ZA, Duse AG, Jenkins P, et al. (2005) Antimicrobial resistance in developing countries. Part I: recent trends and current status. Lancet Infect Dis 5: 481-493.

10. McGaw LJ, Eloff JN (2008) Ethnoveterinary use of southern African plants and scientific evaluation of their medicinal properties. J Ethnopharmacol 119: 559574
11. Burt SA, Reinders RD (2003) Antibacterial activity of selected plant essential oils against Escherichia coli O157:H7. Lett Appl Microbiol 36: 162-167.

12. Prasad C, Mishra RP, Ali A, Gangawar VS, Chand S (2013) Isolation and characterization of multi drug resistant super pathogens from soil samples collected from hospitals, Res J Recent Sci 124-129.

13. López P, Sánchez C, Batlle R, Nerín C (2005) Solid- and vapor-phase antimicrobial activities of six essential oils: susceptibility of selected foodborne bacterial and fungal strains. J Agric Food Chem 53: 6939-6946.

14. Lokesh R, Erayya, Kumaranag KM, Chandrashekhar N, Khan ANA (2014) In vivo efficacy of some antibiotics against bacterial blight of Pomegranate caused by Xanthomonas axonopodis pv. Punicae, Int Res J Biological Sci. 3: 31-35.

15. Verma NK, Vibha, Kumar A (2013) A comparative study of heavy metals in Emblica officinalis Phyllanthus emblica and Azadirachta indica, Int Res J Biological Sci 2: 16-19.

16. Bae EA, Han MJ, Kim NJ, Kim DH (1998) Anti-Helicobacter pylori activity of herbal medicines. Biol Pharm Bull 21: 990-992.

17. Cai L, Wu CD (1996) Compounds from Syzygium aromaticum possessing growth inhibitory activity against oral pathogens. J Nat Prod 59: 987-990.

18. Li Y, Xu C, Zhang Q, Liu JY, Tan RX (2005) In vitro anti-Helicobacter pylori action of 30 Chinese herbal medicines used to treat ulcer diseases. J Ethnopharmacol 98: 329-333.

19. Prasad G, Kumar A, Singh AK, Bhattacharya AK, Singh K, et al. (1986) Antimicrobial activity of essential oils of some Ocimum species and clove oil. Fitoterapia 57: 429-432.

20. Opalchenovaa G, Obreshkova D (2003) Comparative studies on the activity of basil an essential oil from Ocimum basilicum L. against multidrug resistant clinical isolates of the genera Staphylococcus, Enterococcus and Pseudomonas by using different test methods. J Microbiol Methods. 54: 105-110.

21. Singh G, Kapoor IP, Singh P, de Heluani CS, de Lampasona MP, et al. (2008) Chemistry, antioxidant and antimicrobial investigations on essential oil and oleoresins of Zingiber officinale. Food Chem Toxicol 46: 3295-3302.

22. Michielin EM, Salvador AA, Riehl CA, Smânia A Jr, Smânia EF, et al. (2009) Chemical composition and antibacterial activity of Cordia verbenacea extracts obtained by different methods. Bioresour Technol 100: 6615-6623.

23. Deba F, Xuan TD, Yasuda M, Tawata S (2008) Chemical composition and antioxidant, antibacterial and antifungal activities of the essential oils from Bidens pilosa Linn. Var. Radiata. Food Control 19: 346-352.

24. Pankaj S, Al-Tamimi B, Al-Nassri N, Al-Mamari R (2012) Effect of temperature on antibiotic properties of garlic (Allium sativum L.) and ginger (Zingiber officinale Rosc.). African Journal of Biotechnology. 11: 16192-16195.

25. Onyeagba RA, Ugbogu OC, Okeke CU, Iroakasi O (2004) Studies on the antimicrobial effects of garlic (Allium sativum Linn), ginger (Zingiber officinale Roscoe) and lime (Citrus aurantifolia Linn). African Journal of Biotechnology 3: $552-554$.

26. Sinha GK, Gulati BC (1990) Antibacterial and antifungal study of some essentia oils and some of their constituents. Indian Perfum 34: 126-129. 